\title{
REVIEW \\ John Connelly \\ From Enemy to Brother: \\ The Revolution in Catholic Teaching on the Jews, 1933-1965
}

(Cambridge, Massachusetts and London:

Harvard University Press, 2012), 376 pp.

Maria Chiara Rioli, Scuola Normale Superiore (Pisa)

Among scholars of modern Jewish-Catholic relations, John Connelly's book From Enemy to Brother: The Revolution in Catholic Teaching on the Jews, 1933-1965 has rightly gained wide attention. Connelly, professor of History at the University of California Berkeley, drew on bulletins, journals, and books issued from the thirties to the sixties and sources stored in archives at Seton Hall University (John Oesterreicher's papers) and in Munich (Karl Thieme's papers), Vienna, and Washington. The book explores, through a chronological approach, the shift that occurred in Catholic attitudes toward the Jews and the move away from a long tradition of Catholic antiJudaism and antisemitism toward new, more positive views. Connelly reconstructs this fundamental change, tracing an international network of protagonists who contributed, before and during the Second Vatican Council, to ideas that shaped the Council's declaration Nostra Aetate on non-Christian religions (particularly chapter 4 , on the Jews).

He mainly focused on groups of Catholics who, since the thirties and in opposition to Nazism, had developed new reflections on Christian-Jewish relations in Europe and the United States. Among them, Connelly devoted his attention particularly to converts to Catholicism from Judaism and Protestantism (primarily Johannes M. [John] Oesterreicher, but also Gregory Baum, Leo Rudloff, and Paul Démann). 
Connelly's thesis is precisely that without the contribution of these converts, the Church could not have arrived at a reconsideration of its position in relation to the Jewish world. Although the phenomenon of conversions is being considered with growing interest by scholars (not only those studying the modern age), many focus on biographies, and the historical narrative of networks connecting the converts, clergy, and intellectuals is still limited.

One of the most convincing parts of the book is the analysis of the major role some converts played in pushing to change Catholic teachings about Jews and Judaism. Following this process, Connelly compellingly illustrates their contributions. He defines them as "border-crossers": "The great majority of Catholics who wrote on the race question [about whether Jews were a race and not able to become Catholics] were Jewish converts, and virtually every figure of note in the Catholic battle against antisemitism was a convert....the irony of conversion, of crossing a border supposedly with no return, is that one never entirely leaves the point of origin. And the scandal of racism was that those expecting security in the new Catholic homes were told that they remained alien, 'in fact' racially Jewish" (pp. 63-64). This connotation of the converts as people living along cultural and religious borders between communities is thoroughly examined in the book.

The book begins with a stunning survey of the racist views of prominent early twentieth-century Catholics, among them leading theologians, many denying that even baptism could fully make Jews into Catholics. The author then analyzes some Christian voices against first racism and then against Nazi persecution of the Jews. In particular, Connelly describes a memorandum prepared by Thieme, Oesterreicher, and Waldemar Gurian in 1937, in an effort to obtain an official pronouncement by the Holy See against antisemitism and in favor of the Jews.

Approaching the decade before the Second Vatican Council, Connelly highlights the personal "journey" accomplished by 
some of these converts in a process of rediscovery of the Jewish origins of the Church (p. 189). This spirit inspired the foundation by Oesterreicher of the Institute for JudeoChristian studies at Seton Hall University in 1953, and especially the influential Apeldoorn initiative beginning in 1958 to rethink Christian theologies of Judaism (and Christian readings of Scripture) before the Council.

In the last chapter of the book, Connelly sums up some of the main revisions of the conversionist attitude that for centuries had marked the behavior of Catholic institutions and congregations toward Jews. Starting from a mission intended to get Jews to convert to Catholicism, Oesterreicher, Thieme, and others moved the Church toward a mission of self-redefinition and ressourcement, with new attitudes toward the Jews and to the Church's own Jewish roots. 